\title{
QUALITY EVALUATION OF READY-TO-EAT FISH BALL IN CURRY
}

\author{
A. D. Kolekar and A. U. Pagarkar ${ }^{1}$ \\ Department of Fish Processing Technology and Microbiology, College of Fisheries \\ Shirgaon, Ratnagiri- 415629, Maharashtra, India
}

\begin{abstract}
Fish ball in curry (FBC) was prepared following standard recipe. Prepared FBC was packed in standup pouches and stored at 0 to $-2^{\circ} \mathrm{C}$. The organoleptic scores for overall acceptability of the FBC were slightly decreased within the storage period (12 days). The $\mathrm{pH}$ decreased from 6.38 to 6.07 , while peroxide value increased from 2.27 to 9.47 . The total volatile base-nitrogen (TVB-N) increased from 5.04 to 17.64. The total plate count increased from an initial value of $1.8 \times 10^{2}$ to $2.4 \times 10^{4} \mathrm{cfu} \mathrm{g}^{-1}$ during chilled storage. The Staphylcoccus aureus, Escherichia coli and Salmonella $s p$. were not detected throughout the study period. It was observed that the products stored at 0 to $-2^{\circ} \mathrm{C}$ were acceptable organoleptically, and stable biochemically and microbiologically up to 9 days.
\end{abstract}

Keywords: Catla catla, fish ball in curry, chilled storage, quality evaluation

\section{INTRODUCTION}

The Indian major carps being the high-protein food form a major component of the Indian aquaculture, but some carps have limited consumer acceptability because of the presence of intramuscular bones (Seghal and Seghal, 2002). These carps offer distinct advantages such as white colour of meat, and good taste, whereby offer good scope for value addition (Anon, 2009). Processing of carps into value-added products enhance their acceptability and market value as revealed by the sensory evaluation of the product. Value addition means employing processing methods, specialized ingredients or novel packaging to enhance the nutrition, sensory characteristics, shelf life and convenience of food products (Pagarkar et al., 2011).

Currently consumers particularly urban ones are showing more and more interest in food products which are available in ready-to-eat or ready-to-cook form such as fish fillet, finger, cutlet, patties, burger, sausages and fish balls. Present

\footnotetext{
${ }^{1}$ Corresponding author email: pagarkarau@gmail.com
} 
trends of marketing reflect a rapidly growing demand for such processed foods that are more convenient to handle, store and prepare. Factors responsible for such a situation are increasing number of working women, reasonably increase in income, education, awareness and consciousness towards quality, freshness, nutrition, hygiene and health etc. This has led to the development of several fishery products varied in taste, texture and appearance (Pagarkar et al., 2011). Fish ball in curry is one such product that can be processed as a heat processed product in a suitable fluid medium. Fish ball was prepared as per Indian palate and nutritious product prepared from fish surimi. Surimi is an intermediate product, which has characteristic gelling and elastic properties. Surimi was used to develop products with good appearance, flavor and texture. Texturisation of surimi involves modification of elasticity with ingredients such as starch etc. (Kolekar et al., 2012). Fish ball in curry is ready-to-eat 'convenience' form of product and would be a new appropriate channel in the supermarket chain.

In the present study, an attempt has been made to prepare ready-to-eat fish ball in curry and its shelf life was studied at 0 to $-2^{\circ} \mathrm{C}$ concerning to the microbiological, biochemical and organoleptic characteristics.

\section{MATERIALS AND METHODS}

\section{Preparation of fish surimi}

Fresh catla (Catla catla) of 1.5 to $2 \mathrm{~kg}$ were brought to the laboratory in iced condition. Surimi is the Japanese term for debined fish flesh that has been washed with water and mixed with cryoprotectants for good frozen shelf life (Ninawe and Rathnakumar, 2008). Frozen catla surimi was prepared according to the procedure of Huang and Awad (1996). After heading, gutting, filleting, mincing, washing, the meat was drained and mixed with cryoprotectants (5.8\% sugar, $0.2 \%$ Polyphosphate). This surimi was packed in polythene bag, frozen in plate freezer and stored in cold storage at $-18^{\circ} \mathrm{C}$ for further use.

\section{Preparation of fish ball in curry}

Fish ball in curry was prepared following the recipe developed by Kolekar et al. 2012 (Table 1 and flow chart 1).

\section{Chill storage of the fish ball in curry}

Prepared fish balls in curry were stored at 0 to $-2^{\circ} \mathrm{C}$. Samples were drawn at 3 days intervals during storage and organoleptic, biochemical and microbiological analysis of samples were carried out. The proximate composition of fish ball was determined at the beginning and end of storage following standard methods (AOAC, 2005). The $\mathrm{pH}$ was recorded using a $\mathrm{pH}$ meter of EQUIPS-TRONICS model EQ-610 (AOAC, 2005). The peroxide value of fish ball in curry was determined and expressed as milliequivalent of $\mathrm{O}_{2} / \mathrm{kg}$ fat (AOAC, 2005). A TVB-N content of fish ball in curry was determined by the procedure given by Beatty and Gibbons (1937) 
using Conway micro-diffusion units and results were expressed in terms of nitrogen mg/100g. Samples were analyzed for Total Plate Count (TPC) as well as E. coli, S. aureus and Salmonella sp. counts following methods described by USFDA (2001).

Table 1: Recipe of catla fish ball in curry (Kolekar et al., 2012)

\begin{tabular}{cll}
\hline SN & Ingredients & (g) Quantity \\
\hline 1. & Fish surimi & 100 \\
2. & Salt & 2 \\
3. & OS:MS* (60:40) & 15 \\
4. & Curry paste & 40.20 \\
\hline * OS= Ordinary starch, MS= Modified starch & \\
Curry paste is this another table? & \\
\hline 1. & Onion paste & 24.60 \\
2. & Tomato paste & 4.92 \\
3. & Garlic paste & 3.34 \\
4. & Chilli powder & 0.82 \\
5. & Turmeric powder & 0.37 \\
6. & Coriander seed powder & 0.62 \\
7. & Garam masala & 0.87 \\
8. & Green chilli paste & 1.00 \\
9. & Coriander paste & 0.90 \\
10. & Ginger paste & 0.51 \\
11. & Salt & 2.25 \\
\hline Orgal & & \\
\hline
\end{tabular}

Organoleptic evaluations were conducted as per Indian Standard Institute guide for sensory evaluation of foods (ISI, 1975). The prepared fish ball in curry was subjected to organoleptic evaluation by the group of 10 trained panelists by using a 9 point hedonic scale. The various characteristics viz., appearances, colour, taste, texture, odour and overall acceptability were evaluated at 3 and 15 days intervals during the period of chilled storage respectively. 
Flow chart 1: Standardized method of fish ball in curry preparation

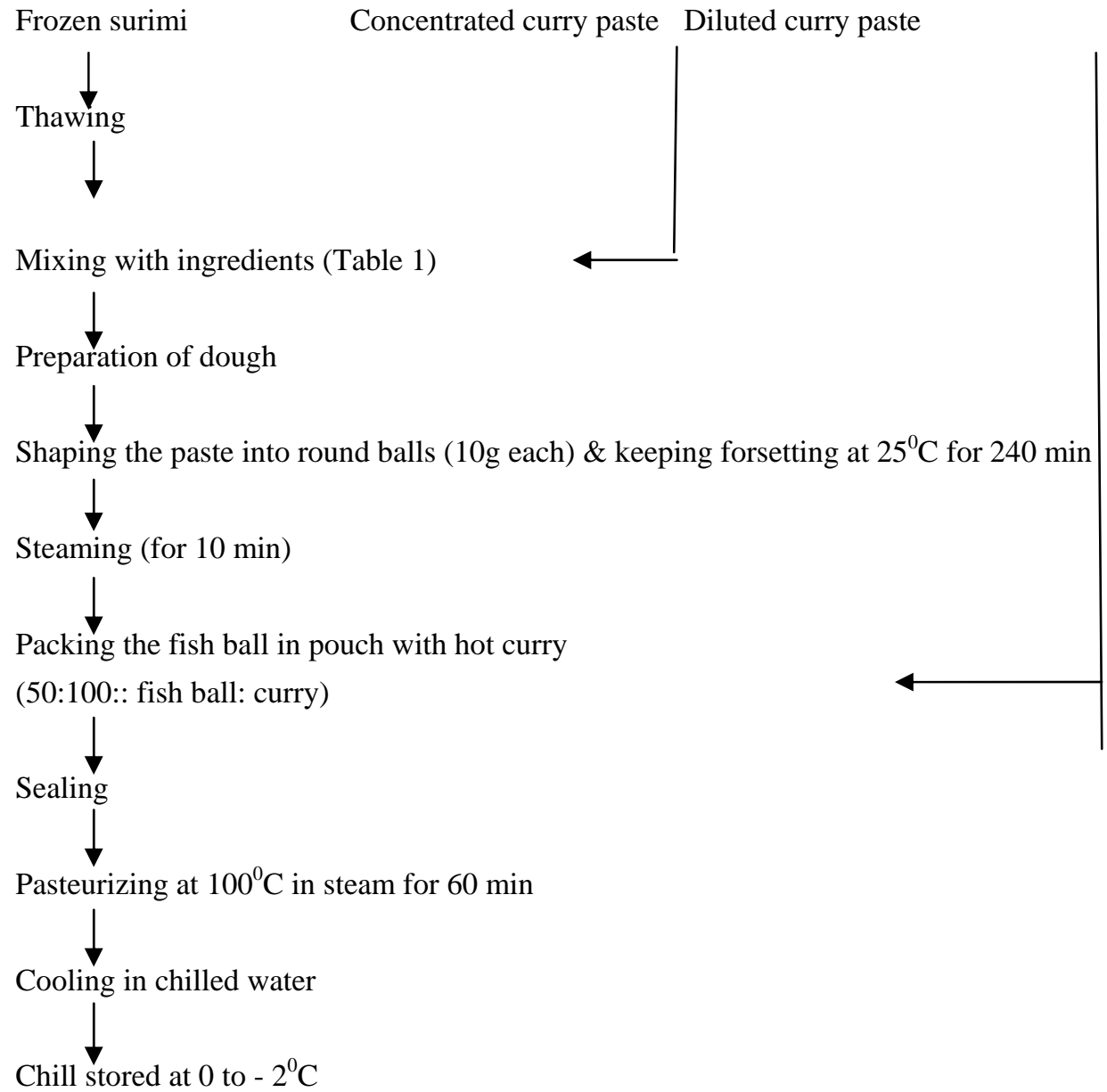

\section{RESULT AND DISCUSSION}

The results of organoleptic evaluation of fish ball in curry kept in chilled storage $\left(0\right.$ to $\left.-2^{\circ} \mathrm{C}\right)$ showed a declined trend of organoleptic scores from 9.0 to 3.1 (Figure 1) for the storage period of 0 to 12 days. Fish ball in curry kept in chilled storage was not acceptable after 9 days. Similar results in organoleptic characterstricts were reported by Kamat (1999). Fish ball in curry prepared from bleached mackerel mince did not show much change in the appearance, colour and texture during storage at 0 to $-2^{\circ} \mathrm{C}$. Undeland and Lingnert (1999) studied lipid oxidation in fillets of herring (Clupea harengus) during frozen storage. The decrease in overall acceptability in fillets was found to be due to formation of some volatile low molecular weight compounds, lipid oxidation and protein degradation during chilled storage. 
In the present study fish ball in curry stored in chilling temperature $\left(0\right.$ to $\left.-2^{\circ} \mathrm{C}\right)$ showed a decrease in $\mathrm{pH}$ from 6.38 to 6.07 (Figure 2). Kamat (1999) also reported sharp decrease in $\mathrm{pH}$ of fish ball in curry during storage. Balange et al. (2004) reported similar findings, where $\mathrm{pH}$ decreased from 5.90 to $4.2 \mathrm{pH}$ during studied the chill stored fish ball in curry. Decrease in $\mathrm{pH}$ of fish ball in curry could be due to the growth of heat tolerant bacteria during storage that had survived at heat processing and then multiplied at chilling temperature. This was also reflected by increase in total plate count during storage. Generally bacteria prefer carbohydrates for immediate use and later go in for utilization of protein. Under such circumstances there would be production of acids and subsequently reduction in $\mathrm{pH}$ (Frazier and Westhoff, 1988).

The peroxide value (PV) in chilled fish ball in curry showed an increasing trend from 2.27 to $9.47 \mathrm{meq}$ of $\mathrm{O}_{2} / \mathrm{Kg}$ (Figure 3). Similar trend was also recorded by Todkari (2005), accounting a PV from 1.20 to 12.50 meq of $\mathrm{O}_{2} / \mathrm{Kg}$ for fish ball in curry chilled stored at 0 to $-2^{\circ} \mathrm{C}$. Kamat (1999) reported gradual increase in PV of fish ball in curry from 2.9 to 3.6 meq of $\mathrm{O}_{2} / \mathrm{Kg}$ during the chilled storage, Peroxide value within the acceptable limit i.e. below 10 (Ninawe and Rathnakumar,2008). Peroxide value (PV) is a measure of the degree of oxidation in the fat (Gopakumar, 2002). The peroxide value was employed for determining the formation of primary products due to oxidation during the storage. Oxidative rancidity is very complex deterioration in which oxygen first reacts with unsaturated fat (lipid) to form hydroperoxides, which then breaks down into substances that render the objectionable rancid flavour. The PV is a measure of first stage of rancidity.

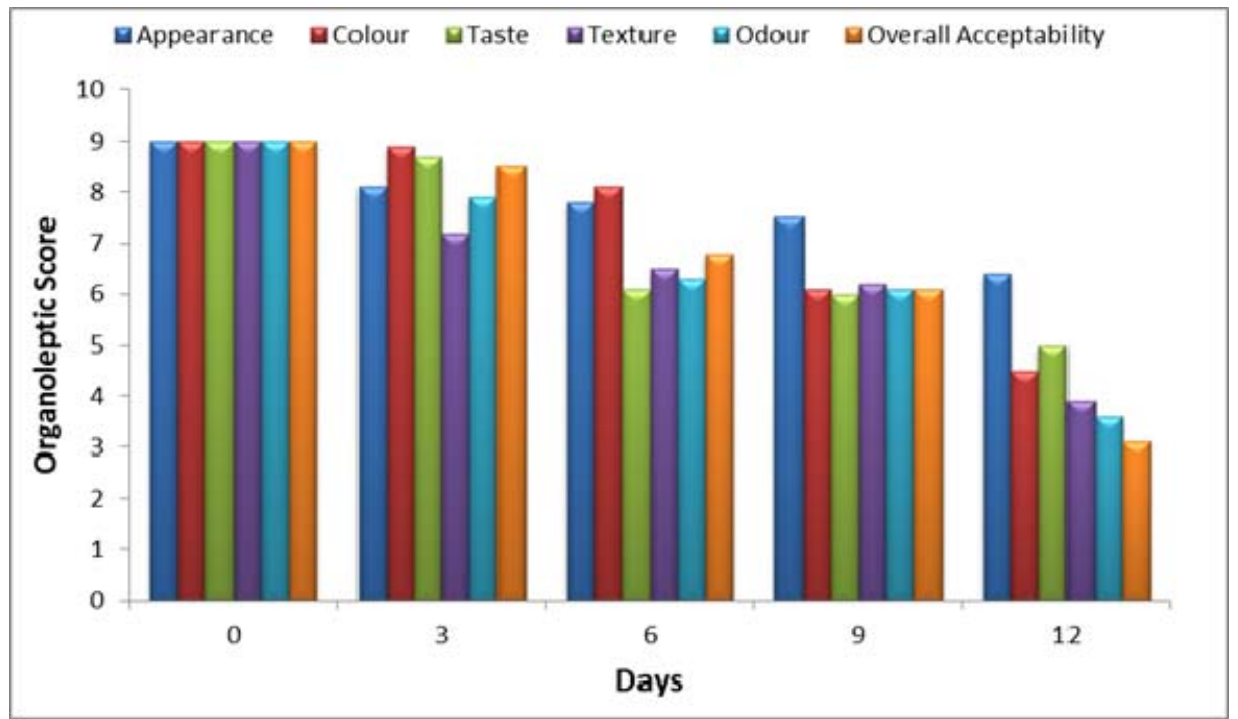

Figure 1. Organoleptic evaluation of catla fish ball in curry during chilled storage at 0 to $-2^{\circ} \mathrm{C}$ for 12 days. 


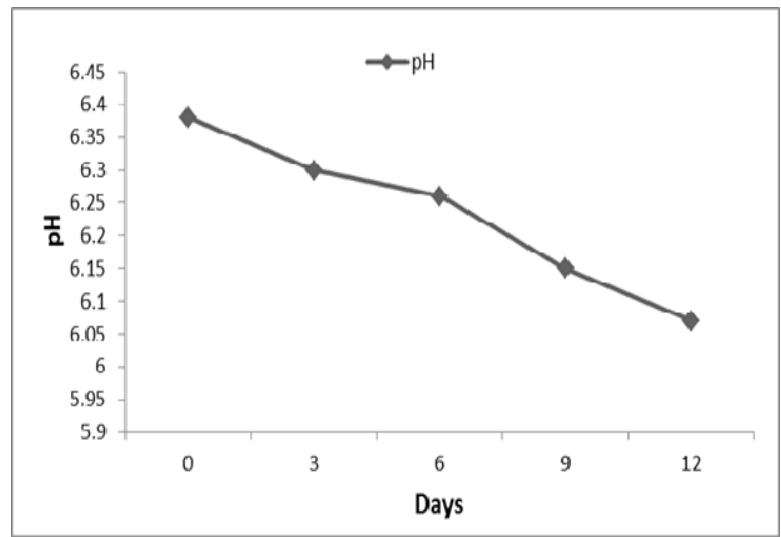

Figure 2. Changes in $\mathrm{pH}$ of catla fish ball in curry during chilled stored at 0 to $-2^{\circ} \mathrm{C}$ for 12 days

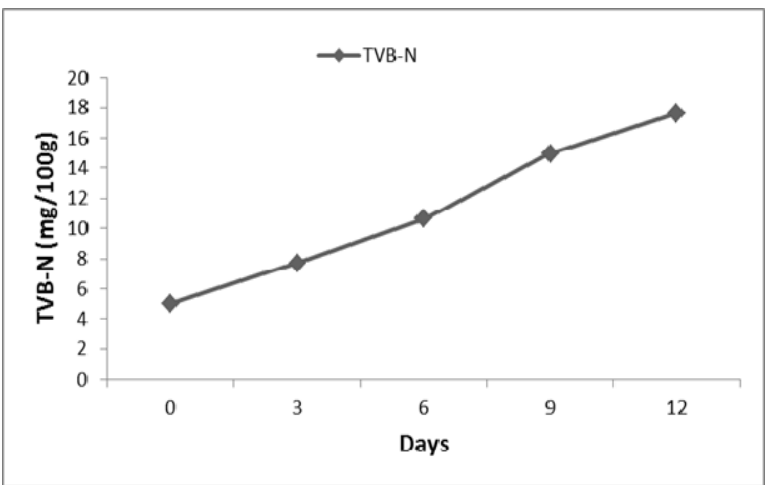

Figure 4: Changes in TVB-N (mg/100g) of catla fish ball in curry during chilled storage at 0 to- $2^{\circ} \mathrm{C}$ for 12 days

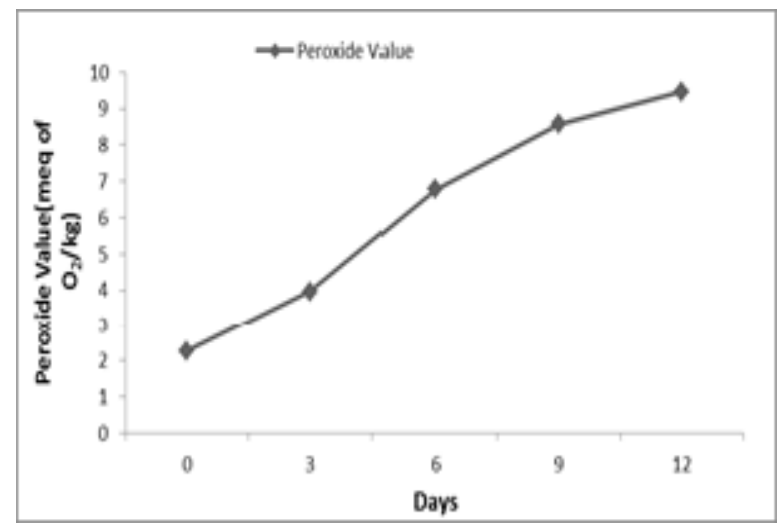

Figure 3: Changes in peroxide value of catla fish ball in curry during chilled storage at 0 to $-2^{\circ} \mathrm{C}$ for 12 days 


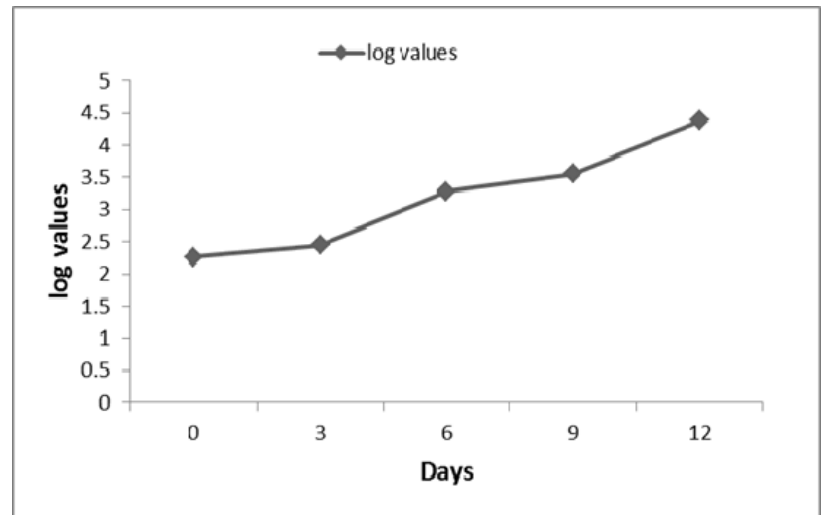

Figure 5: Changes in TPC of catla fish ball in curry in chilled storage at 0 to $-2^{\circ} \mathrm{C}$ for 12 days

TVB-N of catla fish ball in curry stored in chilled storage showed increasing trend from 5.04 to $17.64 \mathrm{mg} 100 \mathrm{~g}^{-1}$ (Figure 4). Increasing values of 6.10 to $9.4 \mathrm{mg}$

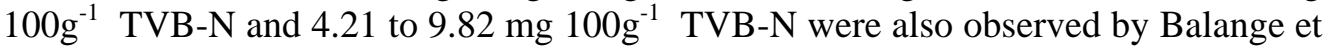
al. (2004) and Mote (2001) in cooked and chill stored fish ball in curry and in cooked and chill stored fish ball in spinach curry, respectively. These values are within acceptable limit. TVB-N values above $35 \mathrm{mg} 100 \mathrm{~g}^{-1}$ in the sample is considered as unacceptable for human consumption. TVB-N is a commonly used chemical method to determine spoilage of fish. The TVB-N in freshwater fish and their products comes from ammonia (Tokur et al., 2004).

The total plate count (TPC) of the fish ball in curry in chilled storage was increased from $1.8 \times 10^{2}$ to $2.4 \times 10^{4} \mathrm{cfu} \mathrm{g}^{-1}$ (Figure 5) and other pathogenic bacteria viz. S. aureus, Salmonella sp. and E. coli were not detected. Kamat (1999) reported TPC of fish ball in curry prepared from mackerel ( $R$. kanagurta) stored in chilled temperature was $3.1 \times 10^{4}$ to $4.1 \times 10^{7} \mathrm{cfu} \mathrm{g}^{-1}$ during storage period of 14 days. Mote (2001) found the TPC values of chilled stored fish ball in spinach curry ranging from $1.70 \times 10^{4}$ to $5.70 \times 10^{7} \mathrm{cfu} \mathrm{g}^{-1}$. Heat processing applied for the fish ball in curry might kill vegetative cells of bacteria but the spore formers might survive in the process and possibly grew in the later stage during chilled storage.

Catla fish ball in curry kept in chilled storage showed slight variation in moisture (68.12 to $66.75 \%)$, protein (15.73 to $14.26 \%$ ), carbohydrate (4.22 to $4.09 \%)$, fat (8.75 to $11.05 \%)$ and ash (3.18 to 3.85\%) content at the beginning and the end of the storage period (Table 2). Similarly, Ninan et al. (2008) and Pawar (2011) reported a slight variation in proximate content of fish cutlet which was due to dehydration and protein denaturation fish muscle during cooled and chilled storage. 
Table 2: Proximate composition of catla (Catla catla) fish ball in curry at the beginning and at the end of chilled storage study

\begin{tabular}{|c|c|c|}
\hline \multicolumn{3}{|c|}{ Proximate composition } \\
\hline \multirow{2}{*}{ Attributes } & \multicolumn{2}{|c|}{ Chilled stored fish ball in curry } \\
\hline & Initial & Final \\
\hline Moisture (\%) & 68.12 & 66.75 \\
\hline Protein (\%) & 15.73 & 14.26 \\
\hline Fat (\%) & 8.75 & 11.05 \\
\hline Carbohydrate (\%) & 4.22 & 4.09 \\
\hline Ash (\%) & 3.18 & 3.85 \\
\hline
\end{tabular}

\section{CONCLUSION}

Ready-to-eat fish ball in curry prepared using a standard recipe has good taste. Fish ball in curry stored at 0 to $-2^{\circ} \mathrm{C}$ showed organoleptic, biochemical as well as microbiological quality analysis values to be within acceptable limit up to 9 days.

\section{REFERENCES}

AOAC, 2005. Official methods of analysis of the Association of Official Analytical Chemists International, $18^{\text {th }}$ edition, In Horwitz, W. (Ed.), AOAC, Washington (D. C.), 35: 2-36.

Anon .2009. Handbook on fisheries statistics 2008. Department of Animal Husbandry, Dairying and Fisheries. Ministry of agriculture, Govt. of India, New Delhi.

Balange A. K., Joshi, V.R. and Pagarkar, A.U. 2004. Preparation of pasteurized fish ball in curry and its storage study. Journal of Indian Fisheries Association, 30: 141-148.

Beatty S. A. and Gibbons N. E. 1937. The measurement of spoilage in fish. Journal of the Biological Board of Canada, 3: 77-81.

Devadasan K., Varma P. R. G. and Venkataraman R. 1978. Studies on frozen storagecharacteristics of fillets from six species of fresh water fishes. Fisheries Technology, 15: 1-6.

Dun A. S. and Rustad T. 2008. Quality of superchilled vacuum packed Atlantic Salmon (Salmo salar) fillets stored at -1.4 and $-3.6^{\circ} \mathrm{C}$. Food Chemistry, 106:122-131.

Frazier W. C. and Westhoff D. C. 1988. Food Microbiology, Tata McGraw-Hill Publishing Company Limited.

Gopakumar, K. 2002. Textbook of Fish Processing Technology, Directorate of Information and Publishing of Agriculture. ICAR, New Delhi, pp. 18-30. 
Huang W. Y., Abdel-Aal H. A. and Awad A. H. 1996. Properties of surimi made from tilapia. In: Nineteenth and twentieth annual conferences of Tropical and Subtropical Seafood Science and Technology Society of the Americans.

ISI, 1975. Indian Standard Institute guide for sensory evaluation of foods, Part III, Statistical Analysis of Data, Indian Standard Institute, (Part III), IS: 6273.

Kamat A. K. 1999. Preparation of fish ball and fish cutlet from mackerel mince meat. M.F.Sc. thesis submitted, Dr. Balasaheb Sawant Kokan Krishi Vidyapeeth Dapoli, Maharashtra.

Kolekar, A. D., Pagarkar, A. U., Baug, T.E., Kedar, J. G. and Bhatkar, V. R. 2012. Standardisation of recipe for fish ball in curry from Ctala catla. Asian Journal of Microbiology, Biotechnology, and Environmental, Science, 8 (2): 381-387.

Mote M. V. 2001. Cook-chill storage of fish ball in spinach curry. M.F.Sc. thesis submitted, Dr. Balasaheb Sawant Kokan Krishi Vidyapeeth Dapoli, Maharashtra.

Ninan G., Bindu J. and Joseph J. 2008. Frozen storage studies of minced based products developed from tilapia (Oreochromis mossambicus, Peter 1852). Fisheries Technology, 45(1): 35-42.

Ninawe, A. S. and Rathnakumar, K. 2008. Fish Processing Technology and Products Development, Narendra Publishing House, Delhi,562 pp.

Pagarkar A. U., Joshi V. R., Baug T. E. and Kedar J. G. 2011. Value addition is need of seafood industries. FISHCOOPS, 23(4): 8-17.

Pawar P. 2011. Preparation of battered and breaded product from fresh water fish catla (Catla catla). M.F.Sc. Thesis submitted to Dr. Balasaheb Sawant Konkan Krishi Vidyapeeth, Dapoli, Maharashtra.

Sehgal H.S. and Sehgal G. K. 2002. Aquaculture and socio-economic aspects of processing carps into some value-added products. Bioresourse Technology, 82: 291-293.

Sankar T. V. 2000) Biochemical and storage characteristics of myofibrillar protein (surimi) from freshwater major carps. Ph. D. thesis submitted, Cochin University of Science and Technology, Cochin, pp. 191.

Tokur B., Polat A., Beklevik G. and Ozkutuk S. 2004. Changes in the quality of fish burger produced from tilapia (Oreochromis niloticus) during frozen storage $\left(-18^{\circ} \mathrm{C}\right)$. European Food Research Technology, 218: 420-423.

Undeland I. and Lingnert H. 1999. Lipid oxidation in fillets of herring (Clupea harengus) during frozen storage. Influence of pre-freezing storage. Journal of Agricultural Food Chemistry, 47: 2075-2081.

USFDA .2001) U.S. Food and drug Administration, Bacteriological Analysis Manual. http: www.usfda.com 